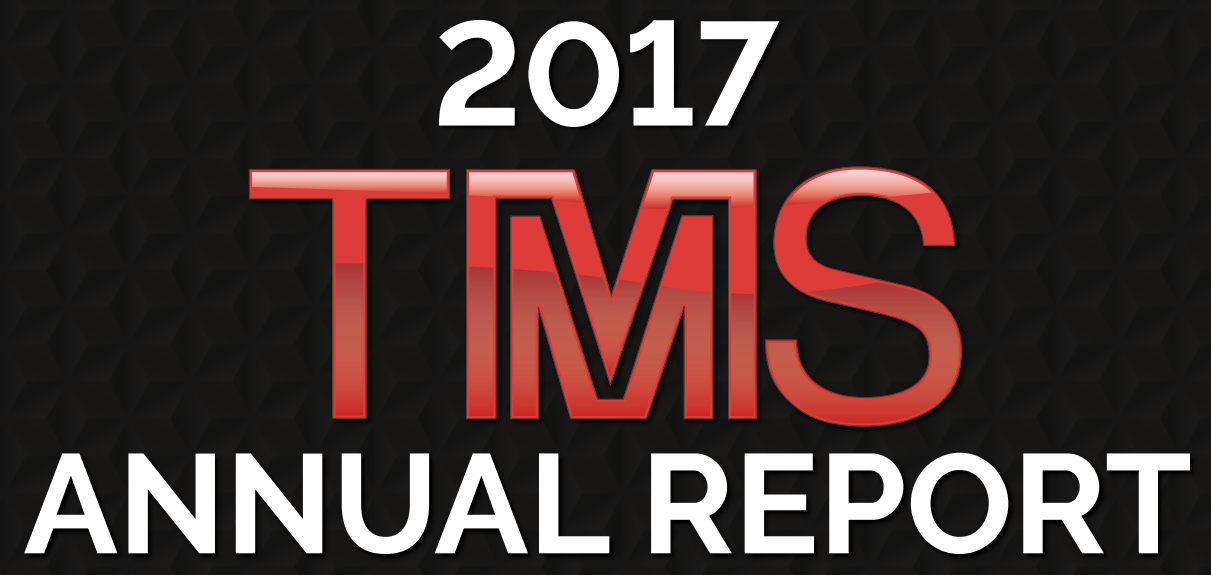

A YEAR OF GROWTH
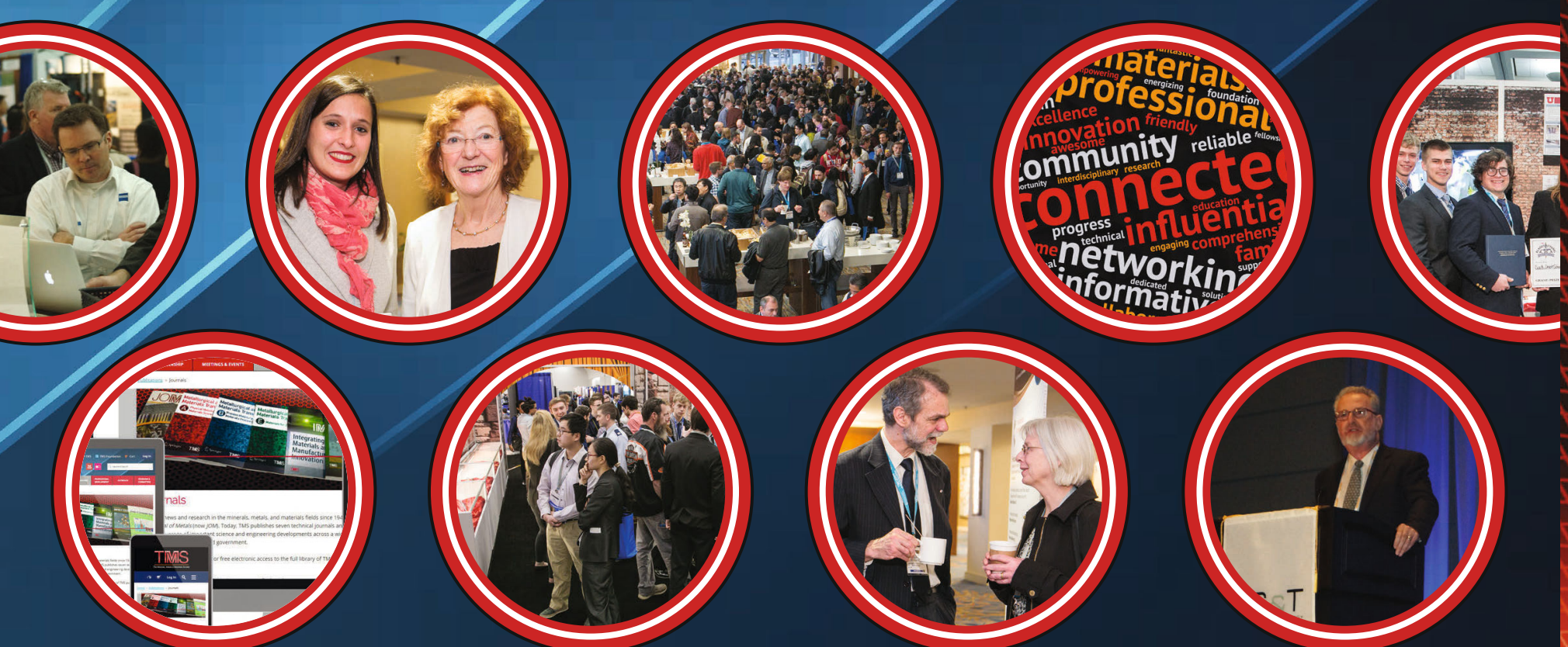

WNAWHIns:org 


\section{WHO WE ARE}

\section{PUBLICATIONS}

The impact factors for TMS's long-established journals have generally been on the rise, demonstrating the growing influence of TMS publications. The chart below shows the progress of these impact factors for JOM, Metallurgical and Materials Transactions A (MMTA), Metallurgical and Materials Transactions $B$ (MMTB), and Journal of Electronic Materials (JEM).

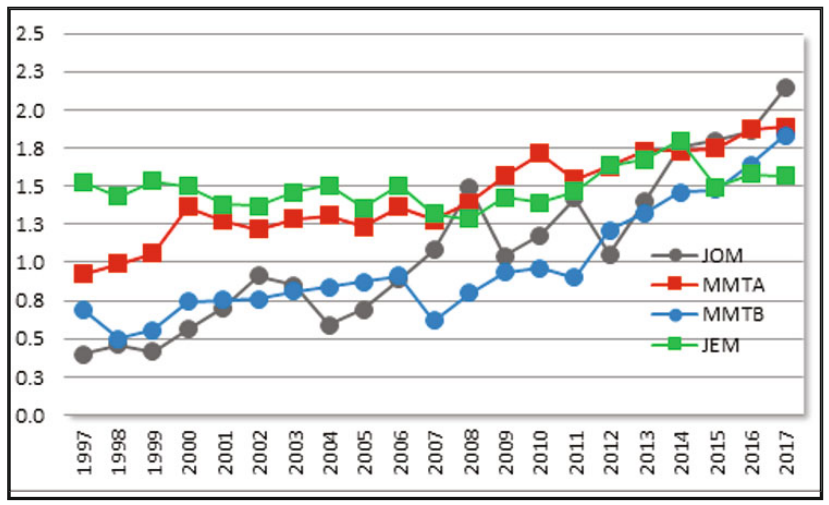

TMS released a new study, Building a Materials Data Infrastructure: Opening New Pathways to Discovery and Innovation in Science and Engineering. conducted on behalf of the U.S. National Science Foundation, and began work on a second report, Harnessing Materials Innovations to Support Next Generation Manufacturing Technologies, organized on behalf of the Alliance for Manufacturing Foresight (MForesight). Funding was also received to begin three new studies, as TMS continues to grow its leadership in the area of developing impactful technical reports for the community.
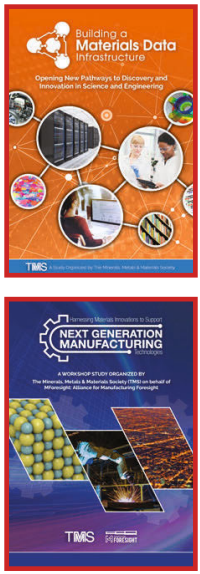

\section{OUR MEMBERSHIP TOTALS}

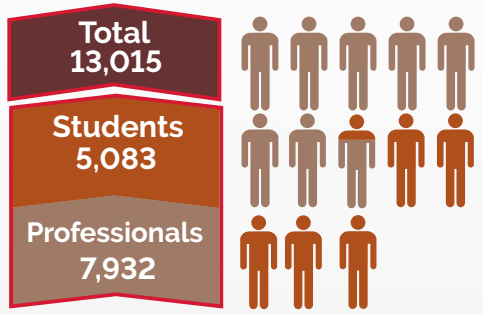

\section{WHERE OUR MEMBERS LIVE}

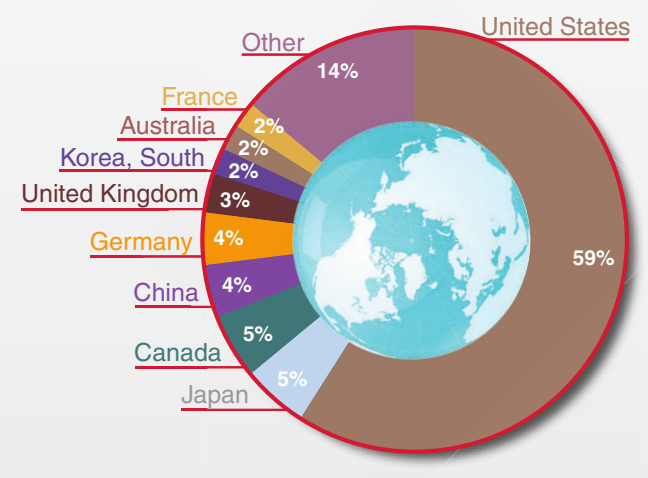

WHERE OUR MEMBERS WORK

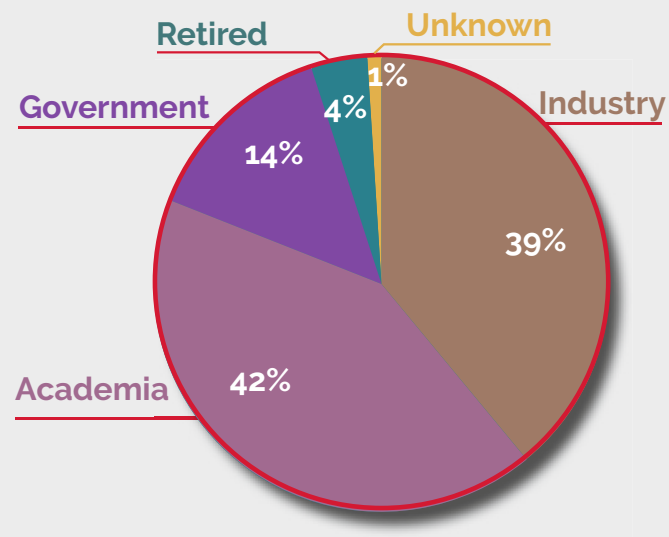

\section{PROFESSIONAL DEVELOPMENT}

The Society offered opportunities for scientists and engineers to enhance their skills with stand-alone courses held at various sites throughout the world. (See listing, right.) Nine professional development courses were also held in conjunction with other TMS meetings.

The TMS awards program also took steps toward growth and change. To ensure greater diversity in its most esteemed class of award winners, the TMS Fellows, TMS established a pair of committees to put guidelines in place that encourage a broader pool of applicants.
2017 PROFESSIONAL DEVELOPMENT COURSES

ALUMINUM

CAST SHOP

science and Technology course

ANODE

TECHNOLOGY

for the Aluminum Industry Course
INDUSTRIAL

ALUMININUM

ELECTROLYSIS

CLUrse on Theory and

CONTROL OF

POTLINE SCRUBBER

\& FUGITIVE EMISSIONS
for Aluminum Smelters course

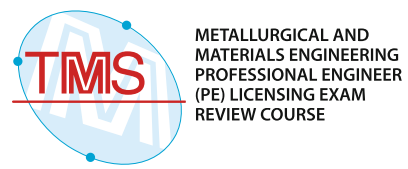




\section{TMS 2017 FINANCIAL REVIEW}

2017 Operating Revenues by Program Area

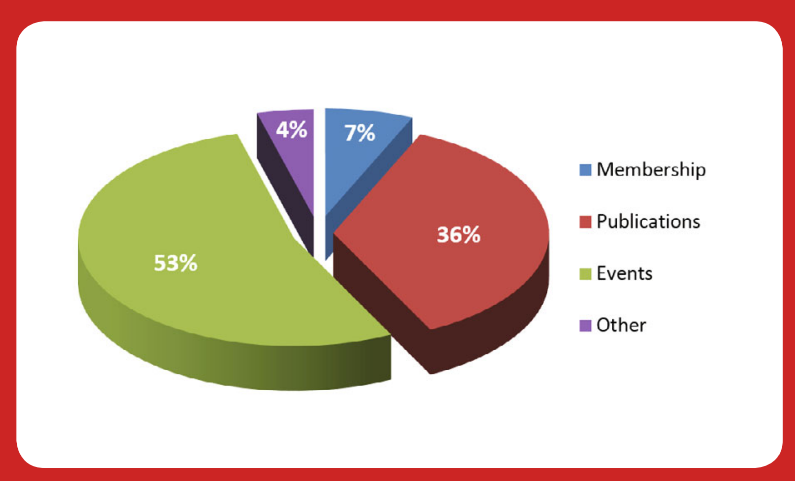

2017 Operating Expenses by Program Area

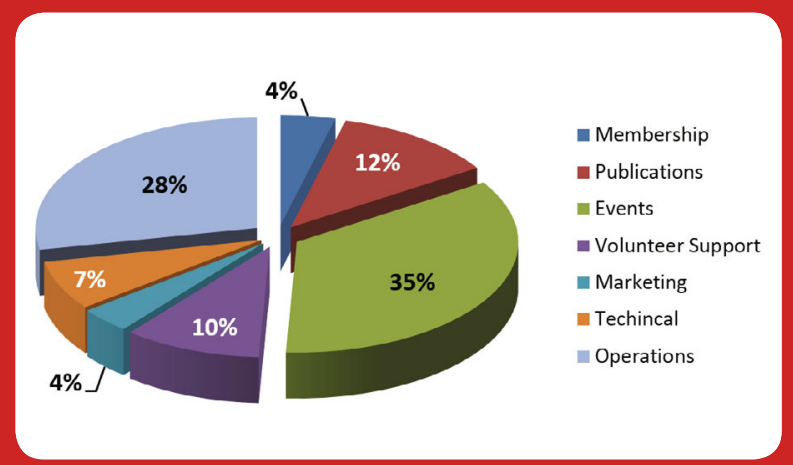

Summary of Operations Revenues and Expenses

\begin{tabular}{|l|c|c|}
\hline REVENUE & \% Total & \\
\hline Membership & $7 \%$ & $\$ 601,462$ \\
\hline Publications & $36 \%$ & $\$ 2,836,722$ \\
\hline Events & $53 \%$ & $\$ 4,142,337$ \\
\hline Other & $4 \%$ & $\$ 335,519$ \\
\hline TOTAL REVENUES & & $\$ 7,916,040$ \\
\hline
\end{tabular}

\begin{tabular}{l|c|c|}
\multicolumn{1}{l|}{ EXPENSES } & $\%$ Total & \\
\hline Membership & $4 \%$ & $\$ 301,701$ \\
\hline Publications & $12 \%$ & $\$ 879,195$ \\
\hline Events & $35 \%$ & $\$ 2,566,141$ \\
\hline Volunteer Support & $10 \%$ & $\$ 741,254$ \\
\hline Marketing & $4 \%$ & $\$ 276,276$ \\
\hline Technical & $7 \%$ & $\$ 531,427$ \\
\hline Operations & $28 \%$ & $\$ 2,111,196$ \\
\hline TOTAL EXPENSES & & $\$ 7,407,190$ \\
\hline
\end{tabular}

\section{TMS ACTIVITY HIGHLIGHTS}

\section{OUTREACH}

TMS reached out to younger members of our community, holding a Bladesmithing Competition for university students at TMS2017 and piloting the Materials Explorers $^{\mathrm{TM}}$ outreach program focused on exposing early high school students to real-world application of science and math concepts.

\section{DIVISIONS \& COMMITTEES}

TMS's attainment of its mission is fueled by its volunteer members, who work in five technical divisions, more than 35 technical committees, and more than 20 functional committees to develop programming, publications, and other society activities. At the top of the volunteer structure is the TMS Board of Directors.

\section{TMS BOARD OF DIRECTORS}

\section{OFFICERS}

\section{David H. DeYoung \\ President}

\section{Kevin J. Hemker}

Vice President

\section{Stanley M. Howard}

Past President

Joy Forsmark

Financial Planning Officer

\section{James J. Robinson \\ Executive Director \\ (non-voting) \\ FUNCTIONAL AREA DIRECTORS}

\section{Michele V. Manuel}

Content Development \& Dissemination

\section{Amy J. Clarke}

Membership \& Student

Development

Chester J. Van Tyne

Professional

Development

\section{Srinivas Chada}

Programming

John A. Howarter

Public \& Governmental Affairs

\section{TECHNICAL DIVISION DIRECTORS}

\section{Cynthia K. Belt}

Extraction \& Processing Division

\section{Raymundo Arróyave}

Functional Materials Division

\section{Alan A. Luo}

Light Metals Division

\section{Corbett C. Battaile}

Materials Processing \& Manufacturing Division

\section{Ellen K. Cerreta}

Structural Materials

Division

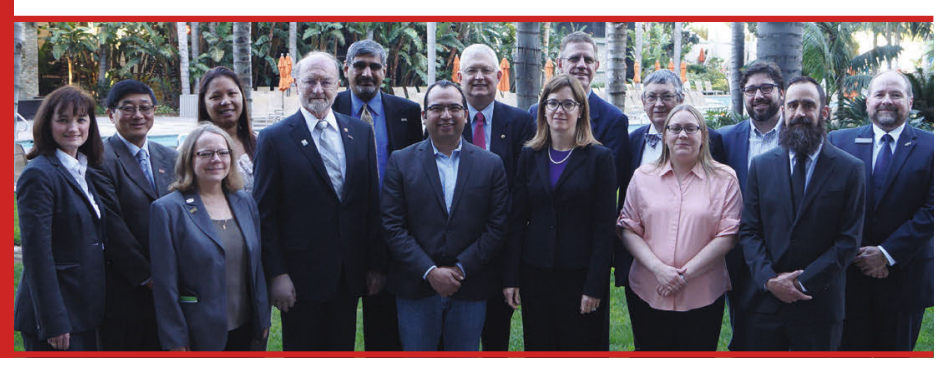

